використовувати роботу в інтерактивному режимі, що передбачено стандартами дистанційної освіти.

Впровадження дистанційної освіти передбачає удосконалення технологій Болонського процесу здійснення підготовки фахівців відповідно до визначеної підприємствами різних видів економічної діяльності та додаткової потреби у персоналі. Головними факторами що використовуються соціальними технологіями у освітянському процесі є: глобалізація та інтернаціоналізація господарської діяльності; поширення стандартів інформаційного суспільства та розвиток новітніх засад інформаційної культури; всесвітній розвиток освітніх систем відкритого типу; модернізація української системи управління відповідно до інтеграції в загальноєвропейський освітній простір (Болонський процес); впровадження інформаційних і комунікаційних технологій у процес традиційного і дистанційного навчання; збільшення масштабів масового централізованого тестування на основі єдиного державного іспиту i тестування; розробка державних освітніх стандартів вищої професійної освіти, що закладають компетентності підходу до навчання i поновому ставлять питання розвитку професійної освіти у рамках сучасних технологій Болонського процесу.

Висновок. Об'єктивна сторона освітньо-виховної політики, відбиваючись у методиці соціальних технологій освіти, регулюється безліччю обставин життєвого простору, важливими серед яких є державний лад, тип та стан економіки, форми власності та засоби розподілу матеріальних та духовних благ тощо. 3 цього можна зробити висновок про те, що освіта та виховання, особливо в інституційному розрізі, суто залежна та багато в чому пов'язана з іншими галузями національної економіки. Сама освіта не може розглядатися поза визначених державних завдань, поза рамками тієї чи іншої ідеології.

\section{СПИСОК ЛІТЕРАТУРИ}

1. Бичків А.В. Інноваційна культура/ А.В. Бичків // Профільна школа. - 2005. - № 6. c. 83 .

2. Візників В.В. Інтернет як компонент інформаційної картини миру i глобального інформаційно-освітнього простору / В.В. Візників, Г.Ю. Соколова, Е.А. Тумалева // Наука і школа. - 2000. - №4. - С. 23-29.

3. Клейман Г.М. Школа майбутнього: комп'ютери в процесі навчання: Пер. с анг. М.: Радио і зв'язок, 1987. - 247 с.

4. Калягін В.I. Нові інформаційні технології та учбова техніка/ В.І. Калягін., Р.К. Михайлов // Вища освіта в Україні. - 1996. №1. - C. 16-21.

5. Кершан Б., Новембер А., Стоун Дж. Основи комп'ютерної грамотності: Перс.с. анг. - М.: Світ, 1989. - 256 с.

6. Фабрика степеней: старая проблема и новые угрозы //http://www.chea.org/degreemills/frmPaper.htm. $5 \mathrm{c}$.

\title{
ПІДВИЩЕННЯ СТАЛОСТІ СОЦІАЛЬНО-ЕКОНОМІЧНОГО РОЗВИТКУ І ЗАБЕЗПЕЧЕННЯ ЕКОНОМІЧНОЇ БЕЗПЕКИ РЕГІОНІВ
}

\author{
Пакуліна А.А., к.е.н, доцент (ХНУБА), \\ Пакулін С.Л., (ДУ «ІЕПСР НАН Украӥни»), \\ Корсунський Г.Ю., студент (ХНУБА)
}

\begin{abstract}
Авторами уточнено поняття «сталість сочіально-економічного розвитку регіону». Розкритий взасмозв'язок сталості з економічною безпекою. Обтрунтована класифікація погроз економічної безпеки регіонального рівня. Розглянуті засоби запобігання, профілактики і ліквідаиіі погроз сталого регіонального розвитку. Доведено, що ефективне функиіонування регіональних

Вісник економіки транспорту і промисловості № 52, 2015
\end{abstract}

(c) Пакуліна А.А.,

Пакулін С.Л.,

Корсунський Г.Ю. 
інтелектуально-інноващійних комплексів сприяє підвищенню сталого соиіально-економічного розвитку території, зниженню погроз економічної безпеки $i$ перетворенню регіональної економіки.

Ключові слова: сталість, сталість соціально-економічного розвитку, економічна безпека, регіон.

\title{
ПОВЫШЕНИЕ УСТОЙЧИВОСТИ СОЦИАЛЬНО-ЭКОНОМИЧЕСКОГО РАЗВИТИЯ И ОБЕСПЕЧЕНИЕ ЭКОНОМИЧЕСКОЙ БЕЗОПАСНОСТИ РЕГИОНОВ
}

\author{
Пакулина А.А., к.э.н, доцент (ХНУСА), \\ Пакулин С.Л., (ГУ «ИЭПУР НАН Украины»), \\ Корсунский Г.Ю., студент (ХНУСА)
}

Авторами уточнено понятие «устойчивость сочиально-экономического развития региона». Раскрыта взаимосвязь устойчивости с экономической безопасностью. Обоснована классификация угроз экономической безопасности регионального уровня. Рассмотрены средства предотвращения, профилактики и ликвидащии угроз устойчивого регионального развития. Доказано, что эффективное функционирование региональных интеллектуально-инновационных комплексов способствует повышению устойчивого соииально-экономического развития территории, снижению угроз экономической безопасности и преобразованию региональной экономики.

Ключевые слова: устойчивость, устойчивость социально-экономического развития, экономическая безопасность, регион.

\section{IMPROVING THE SUSTAINABILITY OF SOCIO-ECONOMIC DEVELOPMENT AND THE ECONOMIC SECURITY OF THE REGIONS}

\author{
Pakulina A., Associate Professor, Cand.Sc. (Econ.) \\ (Kharkiv National University of Civil Engineering and Architecture), \\ Pakulin S., (PA «Institute of Nature Management and Sustainable Development of National \\ Academy of Sciences of Ukraine»), \\ Korsunsky H., Student \\ (Kharkiv National University of Civil Engineering and Architecture)
}

The authors clarified the concept of «stability of the socio-economic development of the region». The stability of the socio-economic system of the region depends on the sustainability of socio-economic systems of higher level, in particular the state. Threat to the economic security of the regions is the lack of development in the areas of economic innovation. In modern conditions the spectrum of threats is expanding, the economic security of Ukraine is undermined not only the economic, but also militarypolitical means. Functions implementation of sustainable socio-economic development of the region leads to the observance of national interests in the region, and promotes economic security. Interaction between stability with economic security. Suggests the classification of threats of economic safety at regional level. The means of prevention, prevention and elimination of threats to sustainable regional development. region.

Keywords: sustainability, sustainability of socio-economic development, economic security,

Постановка проблеми та її зв'язки 3 науковими та практичними завданнями. Підвищення сталості соціально-економічного розвитку і забезпечення економічної безпеки регіонів $є$ важливою науковою проблемою. Актуальність проведеного дослідження і його практична значущість необхідністю підвищення ефективності економіки регіонів України, їх інтеграції для забезпечення економічної безпеки територій. Ці чинники виступають необхідними передумовами досягнення сталого соціальноекономічного розвитку кожного регіону окремо і національної економіки в цілому. 
Аналіз останніх досліджень i публікацій, на які спирасться автор 3 посиланням на джерела. Питання сталого соціально-економічного розвитку i забезпечення економічної безпеки не втрачають своєї актуальності упродовж вже багатьох десятиліть, що знайшло віддзеркалення в працях зарубіжних і вітчизняних учених. Для аналізу сталості соціально-економічного розвитку і забезпечення економічної безпеки нами використані праці вітчизняних вчених, серед яких: В.М. Геєць [1], І.В. Горяна [2], Б.М. Данилишин [3], О.О. Євсєєва [4], В.І. Куценко [5].

Виділення невирішених частин загальної проблеми, котрим присвячується стаття. Вивчення теоретико-методологічної суті проблеми сталого соціально-економічного розвитку регіонів, оцінка напрямів регіонального розвитку, націлених на зниження впливу погроз, забезпечення економічної безпеки виявили відсутність єдиних точок зору. Це визначило мету і завдання проведеного дослідження.

Формулювання цілей статті (постановка завдання). Цілі дослідження: уточнити поняття «сталість соціальноекономічного розвитку регіону»; розкрити взаємозв'язок сталості з економічною безпекою; представити класифікацію погроз економічної безпеки регіонального рівня; виявити засоби запобігання, профілактики і ліквідації погроз сталого регіонального розвитку.

Виклад основного матеріалу дослідження 3 обгрунтуванням отриманих наукових результатів. Існує спільність понять «сталість» і «сталість соціально-економічної системи». На нашу думку під сталістю соціально-економічної системи слід розуміти ії здатність стабільно функціонувати i розвиватися в довгостроковій перспективі в умовах внутрішнього i зовнішнього середовища, що змінюється. Сталий розвиток це умови, що необхідні для збереження $\mathrm{i}$ розвитку потреб і можливостей, і обмеження, які накладаються на можливість задовольняти потреби. В цілому сталий розвиток, на наш погляд, слід досліджувати 3 двох сторін. 3 одного боку, потрібне забезпечення умов збереження потреб і можливостей, і обмеження, що накладаються на можливість задовольняти потреби [6, с. 105]. Індикатором такого підходу у сучасному світі виступає економічна безпека, що дозволяє запобігти впливу негативних дій i забезпечити прогресивний розвиток. 3 іншого боку, потрібний розвиток цих умов, тобто вони мають бути динамічними [7, с. 176]. В цьому випадку індикатором виступають інновації, які дозволяють розвиватися і знаходити нові напрями розвитку економіки.

Безпека i сталість по-різному характеризують стан економіки України як єдиної системи. Сталість характеризує міцність, надійність елементів економічної системи, зв'язків усередині неї. Безпека, у свою чергу, характеризує стан об'єкту в системі, його зв'язків усередині системи, здатність до самовиживання i розвитку, a також дії непередбачуваних i важко прогнозованих чинників. Нам представляється доцільним класифікувати погрози економічної безпеки регіонального рівня. $\mathrm{У}$ найзагальнішому вигляді вони можуть бути класифіковані як внутрішні i зовнішні погрози. До погроз економічної безпеки регіону слід віднести: 1) зовнішньополітичні погрози: розвиток тенденції регіонального економічного i соціально-політичного сепаратизму, зростання міжнаціональної, міжконфесійної і міжетнічної напруженості, здатної призводити до великих конфліктів, внаслідок цього втрата довіри регіонів до центру; 2) економічні погрози: зростаюча міра залежності регіональних економічних систем України від іноземного капіталу, від імпорту продуктів харчування i устаткування, що тягне скорочення регіонального виробництва, гіпертрофоване i неадекватне прибуткам населення зростання сфери послуг, особливо підприємств індустрії розваг, навколо яких концентрується кримінальний актив, шкода здоров'ю населення, що вживає низькоякісні i генетично модифіковані продукти харчування, i як наслідок деградація населення; 3) валютнофінансові погрози: відтік валютних засобів і їх нефункціональне використання викликає скорочення регіонального виробництва внаслідок нерентабельності і неспроможності конкурувати на ринку товарів, зростання безробіття, зубожіння і асоціалізація населення, деструктуризація економічної системи України в цілому. До внутрішніх погроз економічної безпеки регіону відносяться: 1) продовольчі і енергетичні погрози: низька рентабельність регіональних промислових підприємств (за винятком монопольних гігантів, що спеціалізуються на здобичі і переробці газу, на виробництві продукції чорної і кольорової

Вісник економіки транспорту і промисловості № 52, 2015 
металургії і так далі) змушує скорочувати виробництво, що призводить до відкритості регіональних ринків України для імпорту, загостренню цінових диспропорцій в регіонах, падінню виробництва енергії; 2) погрози в реальному секторі: висока зношеність основних виробничих фондів підприємств регіону тягне зниження ефективності кон'юнктурної диверсифікації виробництва устаткування, конкурентоспроможності регіонів, руйнування інвестиційно-інноваційного комплексу, втрата кваліфікованих кадрів, скорочення замовлень на високотехнологічних виробництвах; 3) погрози в соціальній сфері: низька міра бюджетної підтримки економічного розвитку регіонів України (як з національного бюджету, так і із коштів регіональних бюджетів), а також неможливість реалізації бюджетних проектів розвитку виробництва i регіональної інфраструктури приводять до зростання безробіття, зниження життєвого рівня, збільшення соціальних утриманців, втрати трудових навичок.

Дія внутрішніх погроз здатна викликати послідовне накопичення довготривалих руйнівних тенденцій в ключових елементах господарської системи: соціальній сфері; стані і ефективності використання виробничого інноваційного і науково-технічного потенціалу України; економічних стосунках господарювання і управління; стані довкілля; системі економічних і політичних стосунків регіонів один 3 одним i регіонів України 3 центром.

Серйозну i дуже реальну загрозу економічної безпеки регіону і України, на нашу думку, представляє недостатня розвиненість сфери економічних інновацій. Передумовами цього процесу були: розпад науково-дослідних колективів і конструкторських бюро світового класу, згортання фундаментальних досліджень, різке скорочення замовлень на високотехнологічну i конкурентоспроможну продукцію, «витік мізків» з України.

У сучасних умовах спектр погроз розширюється, економічна безпека України підривається не лише економічними, але i військово-політичними засобами. Це особливо характерно для політики розвинених країн по відношенню до інших, менш сильних в економічному і військовому відношенні, держав. Основними засобами запобігання, профілактики і ліквідації погроз являється активна діяльність органів державної влади усіх рівнів і органів місцевого самоврядування. На нашу думку, проведення комплексу робіт 3 профілактики i протидії погрозам у сфері економічної безпеки має бути забезпечене бюджетним фінансуванням. Під економічною безпекою ми розуміємо захищеність громадських стосунків, готовність і здатність інституціональних одиниць українського суспільства розроблювати заходи щодо блокування або нейтралізації можливих або таких, що з'явилися, погроз для реалізації цілей. При цьому об'єктами вивчення економічної безпеки виступають громадяни України, органи місцевого самоврядування, господарюючі суб'єкти на усіх рівнях економіки, держава в особі різних гілок влади державних інститутів.

Висновки даного дослідження i перспективи подальших робіт у цьому напрямку. 1. Дослідження сталого соціальноекономічного розвитку регіону виявило, що одним 3 критеріїв його досягнення $є$ економічна безпека. Суть регіональної економічної безпеки полягає в можливості i здатності економіки регіону поетапно покращувати якість життя населення на рівні загальноприйнятих стандартів, протистояти впливу внутрішніх i зовнішніх погроз при оптимальних витратах усіх видів ресурсів і дбайливому використанні природних чинників, забезпечувати сталий соціально-економічний і суспільно-політичний розвиток регіону.

2. Сталий соціально-економічний розвиток регіону включає традиційні (виробничо-економічні, природно-сировинні, кадрово-ресурсні, соціально-культурні) і специфічні (інноваційні, інфраструктурні) компоненти, необхідні для забезпечення економічної безпеки на рівні не менш граничного значення за рахунок ефективного функціонування регіональних інтелектуальноінноваційних комплексів. Це сприяє підвищенню сталого соціально-економічного розвитку території, зниженню погроз економічної безпеки i перетворенню регіональної економіки. Перспективні дослідження, спрямовані на розвиток теорії i методології кількісної оцінки сталого соціально-економічного розвитку регіону в умовах динамічного довкілля.

Вісник економіки транспорту і промисловості № 52, 2015 


\section{СПИСОК ЛІТЕРАТУРИ}

1. Геєць В.М. Якісні зміни в економіці України $\epsilon$ нагальними // Вісник Національного банку України. - 2014. - № 4(218). - С. 5-9.

2. Горяна I. В. Формування методики оцінювання сталості розвитку регіонів // Економічний аналіз. - 2013. - Т. 14. - № 1. - С. 59-63.

3. Данилишин Б. М. Природноекологічний потенціал в стратегії сталого розвитку України / Б. М. Данилишин // Наука та наукознавство : Міжнародний науковий журнал . -2006 . - № 3. - С. 94-101.

4. Свсєєва О.О. Підвищення стійкості та адаптивності розвитку регіону / О.О. Євсєєва // Економічний простір. - Збірник наукових праць. - № 101. - Дніпропетровськ : ПДАБА, 2015. - C. 72-81.

5. Куценко B.I. Сталий розвиток: стратегія і тактика формування через призму соціогуманітарної сфери / В.I. Куценко. - К.: ДУ ІЕПСР НАН України, 2012. - 168 с.

6. Пакулін С. Л. Державне регулювання i ресурсне забезпечення сталого розвитку соціального комплексу // Економічний простір: 3б. наукових праць. - № 65. - Дніпропетровськ: ПДАБА, 2012. - С. 103-110.

7. Пакуліна А. А. Ефективна і гнучка соціальна політика в умовах глобалізації / А. А. Пакуліна, Г. С. Пакуліна, С.Е. Бондарєв // Вісник економіки транспорту і промисловості. -2015. - Вип. 51. - С. 174-178.

Рецензент д.е.н., професор УкрДУЗТ Кідріна О.Г. Експерт редакційної колегії к.е.н., дочент УкрДУЗТ Полякова О.М.

УДК 330.59.

\title{
МЕТОДОЛОГИЧЕСКИЕ ПОДХОДЫ К ИСССЛЕДОВАНИЮ КАТЕГОРИИ «КАЧЕСТВО ЖИЗНИ»
}

\author{
Тихонравов С.Н., к.т.н., доцент (УкрГУЖТ), \\ Комаренко О.А., аспирантка (ХНУ им. Каразина)
}

\begin{abstract}
Данная статья посвящена анализу методологических основ исследования категории «качество жизни». В работе определены основные направления изучения качества жизни индивида и общества, предпринята попытка выработать критерии требований $\kappa$ содержанию методик оценки качества жизни населения. На основании анализа различных подходов $к$ характеристике качества жизни человека (общества) сделан вывод о необходимости использования комплексного (системного) подхода в соответствии с которым качество жизни рассматривается как субъективно-объективная категория, отражающая единство всех компонентов жизни.
\end{abstract}

Ключевые слова: качество жизни, оценка качества жсизни, индекс качества жизни, благосостояние, степень удовлетворенности индивидов своей жсизнью, смысл и цели существования человека.

\section{МЕТОДОЛОГІЧНІ ПІДХОДИ ДО ДОСЛІДЖЕННЯ КАТЕГОРІЇ «ЯКІСТЬ ЖИТТЯ»}

\author{
Тихонравов С.М., к.т.н., доцент (УкрДУЗТ),
} Комаренко О.О., аспірантка (ХНУ ім. Каразіна)

Дана стаття присвячена аналізу методологічних основ дослідження категорії «якість життя». У роботі визначені основні напрямки вивчення якості життя індивіда і суспільства, зроблена спроба виробити критерії вимог до змісту методик оцінки якості життя населення. 